\title{
Indonesian Legal Political Policy towards Determining Electricity Tariff in the Geothermal Industry
}

\author{
Luhung Kushonggo ${ }^{1}$, Faisal Santiago ${ }^{2}$ \\ Student Program Doctor of Law, Borobudur University ${ }^{1}$, \\ Faculty of Law, Borobudur University ${ }^{2}$ \\ \{luhungkushonggo@gmail.com ${ }^{1}$ \}
}

\begin{abstract}
Indonesia should occupy a very important position for the global political economy of renewable energy because it has the largest geothermal reserves in the world, about $40 \%$ of the world's geothermal resources are in Indonesia. Historically, geothermal development for electric power was carried out in 1926 but until now the use of geothermal energy has been slow and has only reached less than $3 \%$ of the national energy demand and only ranks $2^{\text {nd }}$ country after the United States as the largest producer of geothermal energy. The Indonesian government is having difficulty getting partners or investors to develop the geothermal industry, one of the reasons is the improper electricity tariffs set unilaterally by the government. This research uses a normative juridical method to analyze the determination of electricity tariffs related to the legal system of "Civil Law" and the political configuration in Indonesia that underlies the setting of electricity tariffs, with the intention that geothermal energy can act as a sustainable economic development agenda and help improve the domestic economy.
\end{abstract}

Keywords: Renewable Energy; Geothermal; Electricity Tariff; Civil Law; Political Configuration; Sustainable Economic

\section{Introduction}

The increase in the population along with the development of the economic sector led to an increase in purchasing power and the level of social life of the community that must be met by the state how many public facilities. This increase also fosters industrialization and employment, one of the public facilities needed is the availability of electricity. The construction of public facilities in the form of electricity supply is in order to realize the state's goal in prospering the life of the nation as mandated by the constitution based on Pancasila and the 1945 Constitution.

Perusahaan Listrik Negara (PLN) as the only state-owned electricity provider is tasked to map the projected needs and electricity supply needed so that the available electricity energy can meet the needs of the community. This mapping in addition to household needs also involves the potential consumption of electricity from the Special Economic Zone, Industrial Estate, smelter, priority tourist destinations, consumption of the use of electric motor vehicles and other potential sectors. This mapping is carried out as part of the preparation of the new 
Electricity Supply Business Plan (RUPTL) for the period 2020-2029, RUPTL will certainly refer to the National Energy General Plan of the Ministry of Energy and Mineral Resources where the use of electricity sources from Renewable Energy (Energi Baru Terbarukan-EBT) will be further increased to achieve the target of $23 \%$ or around the contributor of electricity energy needs in 2025. The Ministry of Energy and Mineral Resources with this target then plans for EBT Geothermal should be able to contribute electricity needs of 7,200 MW by 2025.

Geothermal energy is one of the main options to meet targets as a renewable energy contributor to electricity. Indonesia has natural resources around $40 \%$ of the world's geothermal energy reserves that make Indonesia as the country that has the largest geothermal energy potential in the world, but this potential has not been used optimally where only absorbed $4-5 \%$ of the existing capacity. The seriousness of the government to increase the use of geothermal renewable energy was followed up by the House of Representatives (DPR) of Indonesia by passing The Geothermal Law No. 21/2014 (replacing Law No. 27/2003) which separates geothermal activities from other mining activities so that it is allowed to conduct geothermal exploration activities in protected forest areas and conservation areas that have been a legal issue between State Institutions. The development of geothermal energy was not in accordance with the expected where until 2020 the contribution of electricity provided has only reached about $2,130 \mathrm{MW}$ or $30 \%$ of the target that has been announced will be difficult to achieve. "According to the roadmap that is close to realistic, for 2025, it seems that we can only build 3,352.6 MW," said Ida Nurhayatin Finahari, Director of Geothermal Directorate General of Renewable Energy and Energy Conservation of the Ministry of Energy and Mineral Resources.

The development of national Geothermal is still a lot of obstacles even though the government has facilitated with the Geothermal Law and related regulatory regulations, the main problem faced by the government is the lack of interest of investors both in foreign countries as partners for the development and management of geothermal. One of the main problems is the determination of electricity tariffs decided unilaterally by the Government is considered unfavorable to investors in addition to licensing issues and other social issues.

\section{Research Methods}

The method used in writing this research is the method of writing empirical normative law, is a legal research on the application of normative legal provisions (codification, legislation or contracts) in action on every particular legal event that occurs in society. Normative law is a way of writing that is based on analysis of some legal principles and legal theories and laws and regulations that are appropriate and related to the problems in this study. This normative legal research is a procedure and a way of scientific research to find the truth based on the logic of legal science in terms of normative. Empirical law research is conducted by researching directly into the field to see directly the application of legislation or rule of law related to law enforcement, as well as conducting interviews with several respondents, especially from investors who can provide information on the implementation of law enforcement in the framework of the implementation of electricity management Geothermal renewable energy. 


\section{Result and Discussion}

The government realizes that the electricity tariff problem is the main obstacle faced by investors so that it has made several changes regarding the price policy system as follows:

a. Regulation of the Minister of Energy and Mineral Resources No. 14 of 2008 concerning Benchmark Sales of Electricity From Geothermal Power Plants (PLTP).

b. Regulation of the Minister of Energy and Mineral Resources No. 269-12/26/600.3/2008 concerning The Cost of Electricity Supply (BPP) in 2008 provided by PLN, signed by the Director General of Electricity and Energy Utilization (LPE) on June 9, 2008.

c. Regulation of the Minister of Energy and Mineral Resources No. 5 of 2009 concerning Guidelines for The Price of Electricity Purchase by PT. PLN (Persero) From Cooperatives or Other Business Entities. This regulation instructs PLN to implement a plan to purchase electricity using EBT sources with $10 \mathrm{MW}$ with the highest benchmark price. This regulation also revokes the enactment of Regulation of the Minister of Energy and Mineral Resources No. 269 of 2008.

d. Regulation of the Minister of Energy and Mineral Resources Number 32 of 2009 concerning The Benchmark Price of Electricity Purchase by PT. PLN (Persero) from Geothermal Power Plant. This regulation imposes the purchase price of electricity by PLN from pltp sources with the highest benchmark price of 9.70 cents US $\$ \mathrm{kWh}$ for all geothermal working areas (WKP).

e. Regulation of the Minister of Energy and Mineral Resources No. 02 of 2011 concerning Assignment to PLN (Persero) to Purchase Electricity from Geothermal Power Plants and The highest Benchmark Price of Electricity Purchase by PLN (Persero) from Geothermal Power Plants. This regulation revokes the Regulation of the Minister of Energy and Mineral Resources No. 32 of 2009.

f. Regulation of the Minister of Energy and Mineral Resources No. 22 of 2012 concerning Assignment to PLN (Persero) To Purchase Electricity From Geothermal Power Plants and the highest Benchmark Price of Electricity Purchase by PLN (Persero) From Geothermal Power Plants. This regulation determines the purchase price of geothermal electricity by using a benchmark price that is adjusted to the location of electricity purchase by PLN (Persero) with a predetermined amount in the form of a price table. This regulation revokes the Regulation of the Minister of Energy and Mineral Resources No. 02 of 2011.

g. Regulation of the Minister of Energy and Mineral Resources No. 17 of 2014 concerning The Purchase of Electricity From Geothermal Power Plant And Geothermal Steam For Geothermal Power Plant By PLN (Persero). This regulation sets the highest benchmark price of electricity from geothermal power plant based on Commercial Operation Date (COD) and the division of work areas with a predetermined amount in the form of a price table. Furthermore, this price is known as the highest price limit (Ceiling Price) and furthermore the selling price is set forth in the Electricity Sale and Purchase Agreement, in this case the model of the agreement is determined by PT. PLN (Persero). This regulation revokes the Regulation of the Minister of Energy and Mineral Resources No. 22 year 2012.

h. Regulation of the Minister of Energy and Mineral Resources Number 12 of 2017 concerning the Utilization of Renewable Energy Sources for the Provision of Electricity. The purchase of electricity from geothermal power plant by PLN (Persero) can only be done to Power Plant Developers who have geothermal working areas in accordance with proven reserves after exploration. The purchase of electricity from geothermal power plant 
by PLN (Persero) is carried out using the highest benchmark price of The Cost of Supply of Generation in the local electricity system.

i. Regulation of the Minister of Energy and Mineral Resources Number 50 of 2017 concerning the Purchase of Electricity From Geothermal Power Plant And Geothermal Steam For Geothermal Power Plant by PLN (Persero). The regulation regulates the amount of the cost of supply generation per region / distribution / system / sub-system as a reference for the purchase of electricity by PLN. The purchase of electricity from geothermal power plant uses a concept of cooperation to build, own, operate and divert (Build, Own, Operate, and Transfer/BOOT).

The regulation of the Minister of Energy and Mineral Resources No.50 of 2017 is the result of revision of Ministerial Regulation No. 12 of 2017 concerning the regulation of the utilization of renewable energy sources for the provision of electricity. The government is making these changes based on efforts to realize a better business climate by balancing the interests of investors and also working on reasonable and affordable electricity prices by the community. but investors have other views because some statements in the Regulation are considered impartial to the interests of investors.

The disinterest of investors can be seen from the absence of investors who participated in the auction of geothermal working areas (WKP) in 2019 with none of the investors entering the bidding documents. This was responded quickly by the Government to make changes, then the Regulation of the Minister of Energy and Mineral Resources No. 50 of 2017 has been amended for the second time through the Regulation of the Minister of Energy and Mineral Resources No. 4 of 2020 concerning the Second Amendment to Regulation of the Minister of Energy and Mineral Resources No. 50 of 2017 concerning the Utilization of Renewable Energy Resources for the Provision of Electricity and has been enacted by State Gazette number 171 of 2020 dated February 26, 2020 as a continuation of the first amendment to the Regulation of the Minister of Energy and Mineral Resources 50 of 2017. regulation of the Minister of Energy and Mineral Resources No. 53 of 2018.

Regulation of the Minister of Energy and Mineral Resources No. 4 of 2020 has actually been a fairly fundamental change related to the purchase process through direct appointment permitted. Then the replacement of the provisions of Built, Own, Operate and Transfer (BOOT) to Build, Own and Operate (BOO), but still not satisfy the Investors. Investor's dissatisfaction was also conveyed by Hasanudin who stated that the price of electricity from geothermal power plant is indeed a highlight of the developers, there are 2 (two) important things that must be solved about geothermal today is tariff regulation that is not in accordance with economic rules as referred to law No. 21 of 2014 on Geothermal, as well as social risks. Both of these case have had a real impact on the utilization of geothermal renewable energy for the benefit of national electricity energy. Prijandaru stated that financing for geothermal power plant development is easy to obtain if the project meets economic value. Constraints on the development of geothermal plants is the selling price of electricity from the geothermal power plant which is above the reference price of PLN, the determination of electricity tariffs as a public policy often experiences a mismatch between the price of electricity sold by developers and the purchase price of PLN (Persero).

\subsection{The Political Role of law on Public Policy}

The political role of law or legal politics and government policy are 2 (two) things that are interrelated and unwinnable. The legal definition according to Prof. Dr. Van Kan is "The whole rule of life that is coercive to protect human interests in society". Satjipto Rahardjo 
defines The Politics of Law as a voting activity and a way to be used to achieve a certain social and legal purpose in society and certain laws in society. Legal politics must be able to answer fundamental problems are: (1) what objectives to achieve with the existing legal system; (2) what ways and which, it feels best to be used to achieve that goal; (3) when the time of the law needs to be changed and by the means in which it should be made; and (4) can a standard and established pattern be formulated, which can help decide the process of choosing goals and ways to achieve those goals well. Public Policy according to Kraft and Furlong is a government action taken in response to social problems. Social problems are conditions that are widely considered unacceptable to society and therefore require intervention of government involvement, thus it can be stated that The Politics of Law is a mechanism of the creation of legislation that is politically the product of the law in line and controlled by the holders of power in this case is the government in power.

In terms of political interests, the law is seen as a product of the political process as a result of consideration and interests of the ruler formulated in the form of public policy. In terms of public interest, input should come from the aspirations of the community channeled through representatives of the people who are then processed so that it appears as a result in the form of legal regulations or public policy. The mechanism of the formation of laws and regulations under it in the Legal System in Indonesia is a political product. This can be seen from the position of the House of Representatives as holding the power to form legislation and each bill is discussed by the House of Representatives and the President for mutual approval. Similarly, the President has the right to submit a bill to the House of Representatives. Therefore the ratification of a Draft Legislation into Law is a form of mutual agreement between the President (Executive) and the House of Representatives (Legislature) which is none other than as the holder of the power of expropriation.

\subsection{State Legal System}

Currently known there are two main legal tradition groups (principal) that are used as the state law system in the world, namely continental law tradition (civil law tradition) and anglosaksis legal tradition (common law tradition). Countries incorporated into continental law place statutory law as the main joint of its legal system, while countries that adhere to the tradition of anglosactic law make or place jurisprudence as the main joint of its legal system. There are also others who divide the legal tradition into three groups in addition to the two legal traditions above, namely by adding socialist law tradition based on economic and social policy. In addition, there is also a legal system that is rarely discussed by legal experts who can not be classified into one of the three groups above is the state legal system that identifies itself with the tradition of law according to Islamic teachings (the moslem legal tradition). Islamic legal system in the field of economics has existed and been used since the 7th century especially for countries with a majority population and cultured Islam such as the country of Middle East, Iran, Bukhara, Turkey, Nigeria, Mauretania, Mali, India and Indonesia.

The Indonesian legal system relies more on the civil law system which has actually undergone a number of major changes to the Dutch colonial heritage legislation in accordance with socio-cultural conditions in building an integrated national legal system based on Pancasila and the 1945 Constitution. In accordance with Roscoe Pound's theory, namely "Law as a tool of social engineering", which states that the law is as a means of renewal for people who run on a planned basis and can be taken into account. Lawrence M. Friedman's opinion that in order for the legal system in a country to run, it must meet 3 (three) elements, are: Structure (government officials), Substance (legal products) and Legal Culture as legal engine. 
Indonesia is a unique country, rich in noble customs as a social force, with cultural wisdom supported by the 1945 Constitution to facilitate deliberation in resolving a matter that reflects the common law tradition coupled with the majority of the $90 \%$ of the population who are Muslims so that the application of Islamic Law can also be considered in economic conflicts involving the impact on society, especially among Muslims. By looking at the 3 main components above as the complexity of the application of law in Indonesia, the country should have its own legal system with the merger between civil law tradition, Common Law, Socialist Law and Moslem Law as the basis in drafting public policy so that the law that is aspired (Uis Constituendum) especially in determining electricity tariffs from geothermal energy can represent a sense of justice and benefit of all parties, namely for the benefit of the state and investors.

\section{Conclusion}

From the discussion it is known that the basis of public policy making in Indonesia in determining geothermal electricity tariffs applied to the geothermal investors because the legal system used is Civil Law which places the law as the main factor of the legal system. This condition is used as a loophole by the government through legislative and executive institutions to convey its political interests in the name of state interests and ignore the interests of other parties from the economic side. Therefore, the product of Public Policy on electricity tariffs is always considered to benefit one party and harm the other party, especially those who have opposite interests, this will give rise to dilemmas and legal conflicts in the form of rejection of the community in the geothermal business sector at the time of implementation. Therefore, in determining electricity tariffs, it should be done in the stages below.

a. Public policy in the regulation of geothermal electricity tariffs in the manufacturing process should be preceded by studies and research by hearing the aspirations of the community (which concerns social, cultural and religious issues) and involving practitioners and academics in the field of geothermal and economics considering it concerns the interests of people who are mutually beneficial.

b. Public Policy should be flexible by looking at the conditions in the field, especially the response from the community at the time the policy is applied, given the diversity of indonesian society, the policy should consider the social conditions, culture and economic capabilities of the community related both from the electricity provider and electricity users.

c. Based on the diversity of cultures, customs, social and religious status in Indonesia, it is necessary to formulated a new legal system (discovery of law) in accordance with the heterogeneous conditions of this nation with the merger between the concept of legislation (civil law),deliberation (common law), social conditions (socialist law) and elements of religion (codification of Islamic law as the majority religion) will be able to produce the product of public policy law that is aspired (Uis Constituendum).

\section{References}

[1] Abdulkadir Muhammad., Hukum dan Penelitian Hukum, Citra Aditya Bakti, Bandung, p.134 (2004). 
[2] Johnny Ibrahim., Teori dan Metodologi Penelitian Hukum Normatif, Bayu Media Publishing, Malang, p.57 (2006).

[3] Khaled Abou El Fadl, The Islamic Legal Traditional., Cambridge University, UK., p. 295 (2013).

[4] Lawrence M. Friedman, American Law, an Introduction (New York, London, W.W. Norton, second edition, 1998), p. 19-22, dalam B.F Sihombing, Evolusi Kebijakan Pertanahan dalam Hukum Tanah Indonesia, Gunung Agung, Jakarta, 2004, p. 126-127 (2004).

[5] Mochtar Kusumaatmadja, Konsep-konsep Hukum Dalam Pembangunan, Alumni, Bandung, p.21 (2006).

[6] Muchsin dan Fadillah Putra, Hukum dan Kebijakan Publik-Analisis atas Praktek Hukum dan Kebijakan Publik dalam Pembangunan Sektor Perekonomian di Indonesia, (Malang : Universitas Sunan Giri Surabaya dan Averroes Press), p. 17 (2002).

[7] Rianto Nugroho, Metode Penelitian Kebijakan, (Yogyakarta : Pustaka Pelajar), p. 3 (2013) 